\title{
O CARÁTER COMPOSICIONAL DOS CARROS ALEGÓRICOS DAS ESCOLAS DE SAMBA DO RIO DE JANEIRO
}

Pedro Ubirajara Rosa (UCS)

A mensagem e o método de expressar a visualidade artística dependem grandemente da compreensão, capacidade e habilidade de usar as técnicas e os recursos sintáticos visuais. Este artigo reflete sobre o caráter composicional das alegorias das escolas de samba do Rio de Janeiro e propõe considerações sobre algumas especificidades na elaboração desses objetos artísticos.

ESTÉTICA CARNAVALESCA; ESTILO; TÉCNICAS VISUAIS; CARROS ALEGÓRICOS.

ROSA, Pedro Ubirajara. O caráter composicional dos carros alegóricos das escolas de samba do Rio de Janeiro. Textos escolhidos de cultura e arte populares, Rio de Janeiro, v.10, n.2, p. 151-168, nov. 2013. 


\section{THE COMPOSITIONAL CHARACTER OF SAMBA SCHOOLS FLOATS IN RIO DE JANEIRO}

Pedro Ubirajara Rosa (UCS)

The message and the method of expressing visual arts depend on a large scale on the understanding, capacity and ability of using syntactic-visual techniques and resources. This article reflects on the compositional character of allegories of the samba schools in Rio de Janeiro, and proposes some considerations on the specificities of the elaboration of these artistic objects.

CARNIVAL AESTHETIC; STYLE; VISUAL TECHNIQUES; FLOATS.

ROSA, Pedro Ubirajara. O caráter composicional dos carros alegóricos das escolas de samba do Rio de Janeiro. Textos escolhidos de cultura e arte populares, Rio de Janeiro, v.10, n.2, p. 151-168, nov. 2013. 


\section{INTRODUÇÃO}

O desfile de escolas de samba é competição festiva em que se trata de "a um só tempo associar-se e rivalizar" (CAVALCANTI, 1994, p. 21). As escolas de samba constituem grupos sociais locais, geralmente formados pelas camadas populares, "escola do morro" que, por exemplo no Rio de Janeiro, desce o morro literalmente e alcança notoriedade e expansão com outras camadas da sociedade/ cidade (CARNEIRO, 1987; MOURA, 1983; BARBOSA; SANTOS, 1980; CAVALCANTI, 1994; COSTA, 1984; FERREIRA, 2004).

Este artigo aborda a estética carnavalesca tendo como foco o caráter alegórico. Para essa análise, elucidaremos a proposição visual dos desfiles, cujo padrão narrativo é o enredo. Tomaremos, para breve e introdutória explanação, a contribuição de Maria Laura Viveiros de Castro Cavalcanti (1994) e de Milton Cunha (2010); ambos observam que enredo é a narrativa escrita que desemboca na construção do desfile de uma escola de samba. Para a análise da linguagem plástica e visual, tomaremos emprestadas as definições de Dondis (1997) sobre comunicação visual, estilo artístico e técnicas visuais, na perspectiva de identificar características genéricas no processo de confecção alegórica.

\section{ENREDO: PROPOSITOR DA VISUALIDADE} enredos.

Os desfiles das escolas de samba se dão através da encenação de

A narrativa escrita é uma das obrigatoriedades prescritas pela Liga das Escolas de Samba, para julgamento dos quesitos enredo, samba-enredo, alegoria e adereços, fantasias e conjunto. Como ópera de rua (...), o desfile das escolas de samba apresenta um libreto que elucida o seu tema para a comissão julgadora e para a imprensa, em informações condensadas em um único documento (CUNHA, 2010).

Antes de servir para o julgamento desses quesitos, ${ }^{1}$ a construção do enredo serve para associar todo o coletivo da escola de samba. É a partir do enredo que se começa a construir o processo carnavalesco; citemos três aspectos principais no tocante à encenação na avenida:

- confecção do samba-enredo: “a narrativa [do enredo] será cantada na avenida repetidas vezes [pelo samba], sendo, portanto, significativa a transmissão oral, tal qual acontece na tradição africana" (CUNHA, 2010, p. 67);

- confecção dos carros alegóricos: é a expressão visual daquilo que o enredo pretende em sua origem; é sua narrativa plástica; 
- elaboração das fantasias: as fantasias, assim como os carros alegóricos, pretendem expressar visualmente aquilo que o enredo propõe. "A fantasia relaciona toda a escola, situa a posição relativa de cada um no conjunto do desfile (...) envolve a todos, trazendo-os de forma mais ou menos consciente para dentro do enredo" (CAVALCANTI, 1994).

O enredo é, portanto,

de um ponto de vista teórico-conceitual, a proposição de realidade ficcional, descritiva ou até mesmo dissertativa que constitui o fio condutor de sentido de um desfile de escola de samba. É a concepção de base que estrutura toda a realização semiológica do espetáculo que corre por 80 minutos na Avenida (CUNHA, 2010, p. 65).

Sobre a elaboração semiótica do espetáculo discorremos a seguir.

\section{CARROS ALEGÓRICOS}

Carros alegóricos são representações artísticas que, como qualquer outro objeto artístico, emitem mensagens visuais, cabendo-lhes "contar, expressar, explicar, dirigir, inspirar, afetar" (DONDIS, 1997 p.131). São representações que têm como princípio a comunicação visual.

É importante dizer que, embora tenhamos optado aqui por analisar os padrões narrativos e visuais separadamente, quando tratamos de inteligência visual aplicada, conteúdo e forma nunca se dissociam; são inerentes um ao outro, porque o resultado final da experiência visual está na interação de mensagem e significado, que é o conteúdo, com o design, meio e ordenação, que é a forma.

Como qualquer elemento da linguagem, a possibilidade de comunicação depende de habilidades para se expressar aquilo que se intenciona dizer. Nesse sentido, quando um artista propõe seu trabalho ele tende a fazer escolhas e apropriar-se de recursos visuais específicos. No caso da comunicação visual "a inspiração súbita e irracional não é uma força aceitável no design. O planejamento cuidadoso, a indagação intelectual e o conhecimento técnico são necessários no design e no pré-planejamento visual" (DONDIS, 1997, p.136).

Cabe lembrar que o desfile de escola de samba sofre julgamento de pessoas qualificadas e que têm domínio sobre seu quesito específico. ${ }^{2}$ Jurados da parte musical (bateria, samba-enredo) são geralmente músicos de formação; jurados da parte visual (alegorias e adereços, e fantasias) costumam ser artistas plásticos, professores e intelectuais do meio artístico. Esses exemplos servem para situar que deve haver necessariamente suficiente compreensão estética e de comunicação visual na execução de um desfile de escola de samba. 
Interessante que, diferente de artes ditas eruditas, que compõem renomados museus ao redor do mundo, as alegorias carnavalescas (como, aliás, todo o projeto de desfile, seja visual, musical, teatral ou escrito) se valem de uma linguagem popular sem, no entanto, deixar de ser esteticamente sofisticada, o que veremos adiante.

A mensagem e o método de expressar a visualidade artística dependem grandemente da compreensão, capacidade e habilidade de usar as técnicas visuais. A síntese dessas técnicas visuais vai automaticamente formar e personalizar estilos (DONDIS, 1997) - cada estilo artístico, categoria ou classe de expressão visual é modelado pela conjunção de determinadas técnicas visuais. Para fins desta pesquisa, analisaremos o desfile de escola de samba naquele caráter ou estilo que o identifica: o ornamental.

\section{ESTILO}

Segundo Dondis (1997), estilo é a síntese dos elementos visuais, técnicas, sintaxe, inspiração, expressão e finalidade básica. O arquiteto Sulivan (apud DoNDIS, 1997, p. 162), sentia a estrutura imposta do seguinte modo:

Você não pode se expressar a menos que tenha um sistema de expressão; não pode ter um sistema de expressão, a menos que tenha um sistema anterior de pensamento e percepção, não pode ter um sistema de pensamento e percepção a menos que tenha um sistema básico de vida.

É claro que cada artista desenvolve sua grafia pessoal, sua "marca registrada". Se nos é fácil conceber que os sistemas de vida são culturalmente condicionados e que há a precedência de um predomínio cultural, podemos, a partir daí, verificar um estilo individual. Sim, porque existem, em determinado contexto, pistas visuais que em conjunto compreendem a obra de vários artistas sem, no entanto, interferir na individualidade de cada artista.

Sobre a questão da individualidade no universo do carnaval cabe trazer os estudos de Nilton Santos (2006; 2009). O trabalho de Santos, com base em entrevistas de carnavalescos, apresenta a noção de estilo como fator de individualidade. Aqui, o estilo envolve problemática muito discutida. De um lado, aqueles que aderem às formas mais tradicionais de fazer desfile; de outro, aqueles que buscam as soluções inovadoras que, de certa forma, desconstroem uma espécie de estética genérica então estabelecida. Essa discussão surgiu com Joãozinho Trinta, no começo de sua carreira, nos anos 70, e hoje é enfrentada pelo carnavalesco Paulo Barros. 
Segundo Santos (2006), há, por parte dos carnavalescos, uma compreensão de seu ambiente artístico e das "convenções estéticas" que o sustentam. A partir daí começa-se a construir uma forma individual que favoreça sempre uma nova fórmula de espetáculo e que, por conseguinte, sagrará o trabalho do carnavalesco. Não pretendemos focalizar essa problemática, mas é interessante perceber que, mesmo dentro de um sistema de arte com convenções mais ou menos estabelecidas, há um modo pessoal de aglutinar, compor e utilizar as técnicas que regem esse sistema. É possível, a partir das variantes técnicas, identificar a individualidade artística de um autor e, ao ampliar nossa visão, identificar o estilo de toda uma escola ou período em que sua obra se estabelece.

Transparece o dado de que tudo se baseia nas preferências metodológicas - as técnicas visuais manipulativas -, já que o estilo é a síntese da junção de determinadas decisões, forças e fatores compositivos.

\section{ORNAMENTAL: O ESTILO CARNAVALESCO}

Na definição de Dondis (1997, p. 176 e 177), o estilo ornamental enfatiza técnicas visuais discursivas de efeitos cálidos e elegantes. Esse estilo não é só em si mesmo, como também costuma ser associado à riqueza e ao poder. Os efeitos grandiosos que podem produzir constituem um abandono da realidade em favor da decoração teatral e do mundo da fantasia. Em outras palavras, a natureza desse estilo é frequentemente florida e exagerada, configurando um ambiente perfeito para um rei ou imperador (...). Nenhuma escola é mais representativa das qualidade desse estilo do que o barroco. É uma arte em que certamente não há espaço para objetividade ou realidade, não importa a que nível.

O ornamento é forma subordinada a um todo maior, complementada e enriquecida. Rudolf Arnheim (2006) exemplifica isso ao identificar o cetro, a peruca e a coroa como ornatos de um rei ou lembrando os móveis criativamente decorados na tentativa de enriquecer sua aparência. E essa é a ideia, enriquecer a aparência do objeto.

Embora o ornamental seja um estilo que abarque outras escolas e períodos artísticos, segundo a definição de Dondis, o termo barroco é muito utilizado no ambiente carnavalesco e nos estudos que o aprofundam. Tende a significar, assim, a estética à qual o carnaval pertence. Cabe aqui fazer uma breve reflexão a esse respeito.

A escultura barroca, por exemplo, permite múltipla apreciação. Todos os aspectos que constituem o objeto barroco são inseparáveis, mas, ainda assim, 
podem ser contemplados em grande diversidade de formas e ângulos. Provoca, segundo Arnheim (2006, p. 205), "um movimento espiralado de todo o corpo". A obliquidade de um dos segmentos que compõem o objeto é fator de equilíbrio dos demais. As ideias de expansão, concavidade e convexidade, por sua vez, ajudam na animação do objeto. A impressão de Cavalcanti (2006), sobre as alegorias, ilustra essa abordagem barroca:

Com as alegorias, cujo recurso visual primeiro é sempre a monumentalidade, ou seja, o grande aumento em escala dos motivos principais representados (elas são sempre imensas, em regra até $13 \mathrm{~m}$ de altura, 10 de largura e 15 de comprimento), as coisas representadas nos carros ganham uma vida ativa quase humana.

A ideia de monumentalidade, necessária à espetaculização da caixa cênica que é um sambódromo, ${ }^{3}$ está firmada. A disputa competitiva demanda "um ser melhor que o outro", "um ser mais rico que o outro", "um impressionar mais que o outro". Não que o "gigantismo" seja fator preponderante para um julgamento de carnaval. Parece-me, entretanto, consensual a ideia de que, na disputa, uma escola grandiosa sempre acaba impressionando consideravelmente, muitas vezes até ganhando o carnaval como fruto desse tipo de recurso visual. O trabalho carnavalesco demanda muito acabamento e alto nível de decoração. Quanto maior for o carro tende a ser maior a decoração. Esse trabalho é notavelmente percebido no desfile, o que acaba sempre impressionando.

Outra referência do estilo ornamental é a utilização de gêmeos (ARNHEIM, 2006). No caso dos desfiles das escolas de samba, o palco do evento - o popular sambódromo - é ladeado por arquibancadas. Por isso, todos os elementos visuais dispostos do lado direito da alegoria são dispostos igualmente do lado esquerdo. Essa duplicação dá ao público visão praticamente completa do desfile, já que, apesar de ser impossível ver o outro lado da alegoria, sabe-se a provável composição de seus elementos. Esse jeito de conceber a alegoria não é regra, mas notadamente é o recurso mais utilizado. ${ }^{4}$

\section{TÉCNICAS VISUAIS ORNAMENTAIS APLICADAS NO DESFILE DAS ESCOLAS DE SAMBA DO RIO DE JANEIRO}

Já dissemos que, para a construção de um planejamento visual, é necessária enorme habilidade. $\mathrm{O}$ artista que produz uma imagem - imagem que pretende ser significante - precisa dominar um conjunto de técnicas que o auxiliem a expor a mensagem. O que o artista fará é uma composição. Essa composição "é o meio interpretativo de controlar a reinterpretação de uma mensagem visual por parte de quem a recebe" (DONDIS, 1997). Interessante que, no caso dos desfiles 
de escola de samba, esses recursos compositivos são analisados criteriosamente, pois o que está em jogo é o título do carnaval, ou uma colocação razoável entre as "grandes escolas de samba".

Para ilustrar esse caráter avaliativo trarei alguns comentários de jurados colhidos no site da Liga Independente das Escolas de Samba - Liesa (liesa.globo. com) referentes ao Carnaval de 2010 no Rio de Janeiro, com relação à avaliação do quesito Alegoria e Adereços para o G.R.E.S. União da Ilha do Governador. ${ }^{5}$

A escola trouxe o enredo "Dom Quixote de La Mancha, o cavaleiro dos sonhos impossíveis", da consagrada carnavalesca Rosa Magalhães. O jurado determinou a nota 9,6 justificando da seguinte maneira: "o projeto de luminotécnica não deu o efeito que o conjunto escultórico pedia, sem grandes emoções, alegrias; (...) carros pequenos para o conjunto alegórico". Outro jurado deu para a escola a nota 9,8, justificando: "boa distribuição de cores e com acabamento de alta qualidade; o conjunto alegórico reproduziu de forma média o enredo. Podendo ser mais explorado nesse requisito a disposição volumétrica poderia ser melhor trabalhada, bem como a luminotécnica". Outro jurado atribuiu a nota 9,7 assim justificando:

a concepção das alegorias de maneira geral obedeceu a uma escala de proporções pequenas e compactas contrapondo-se a grandiosidade do tema. Na alegoria 02 o revestimento de pedras da casa de D. Quixote merecia melhor solução plástica para representar a textura. $\mathrm{Na}$ alegoria no 04 em função de suas dimensões os elementos escultóricos pareciam exprimidos dificultando a leitura do carro, onde o moinho de vento da parte traseira estava sem uma das pás. No carro no 07 os desenhos de Portinari mereciam melhor destaque pelo foco dado a eles.

Podemos notar, com a amostragem de julgamento, o grau de dificuldade que é exigido ao fazer um desfile de escola de samba desde seu projeto original. O domínio das técnicas deve ser absoluto, e sua aplicação precisa ser muito competente. Segundo Dondis (1997, p. 139) "essas opções constituem o controle do efeito, o que vai resultar numa composição forte", pois são as técnicas visuais que "oferecem ao designer uma grande variedade de meios para a expressão visual do conteúdo. Existem como polaridades de um continuum, ou como abordagens desiguais e antagônicas do significado".

Abordaremos a seguir as técnicas ornamentais estabelecidas por Dondis A. Dondis traçando relações com o perfil estético dos desfiles das escolas de samba. Chamamos a atenção para o fato de que as técnicas a seguir fazem parte do 
estilo ornamental, mas algumas podem ser encontradas em outros estilos mencionados pela autora.

Complexidade - é constituída por inúmeras unidades e forças elementares, resultando num complexo processo de organização do significado de um determinado padrão.

Em seu estudo de campo, Cavalcanti (1994) revela sua impressão quanto à quantidade de elementos que compunham os carros alegóricos da Mocidade Independente de Padre Miguel em 1992, com o enredo "Sonhar não custa nada... ou quase nada" dos carnavalescos Renato Lage e Lilian Rabello:

O carro "Mosquitada desvairada" trazia também imensos mosquitos. O corpo do carro e a cabeça dos mosquitos tinham sido moldados em fibra de vidro, e estavam sendo posicionados, com o auxílio de roldanas e altas escadas, sobre as finas e compridas patas de ferragem. Essa ferragem, mais tarde forrada de espuma, seria ainda pintada em spray com listras verdes e abóbora berrantes. Uma vez pintada, essa espuma seria espetada com milhares de palitinhos banhados numa tinta de cor de ferrugem. Atrás dos mosquitos, erguiam-se os recipientes de inseticida (com os dizeres "insetisono"), feitos de madeira decorados com pequenos espelhos. Sua parte superior, em fibra de vidro era toda forrada de dourado" (p. 157).

São "microcoisas" que se vão aglomerando na composição complexa de um carro alegórico - no trecho "erguiam-se recipientes de inseticida (com os dizeres 'insetisono'), feitos de madeira decorados com pequenos espelhos" é possível verificar a quantidade de elementos expostos para comunicar uma mensagem. Esses elementos, aparentemente desconexos, acabam encontrando unidade, mas numa complexa elaboração visual. "Brincam com a ambiguidade, intrigam, surpreendem" (p. 157).

Profusão - assim como a complexidade a profusão é carregada de acréscimos discursivos, aqui infinitamente detalhados, atenua e embeleza (o discurso, a ideia) através da ornamentação. Está associada a poder e riqueza.

Exagero - recorre a um relato profuso e extravagante; a expressividade busca ir além da verdade; a ideia é intensificar e ampliar.

Já citamos o fator "monumentalidade" que o desfile de escola de samba determina. Essa expansão quase que necessária está fortemente imbricada na concepção alegórica de um desfile.

Rotundidade - seguindo o raciocínio de Arnheim (2006), é possível afirmar que a rotundidade recorre a um padrão visual simples, que é o do círculo e 


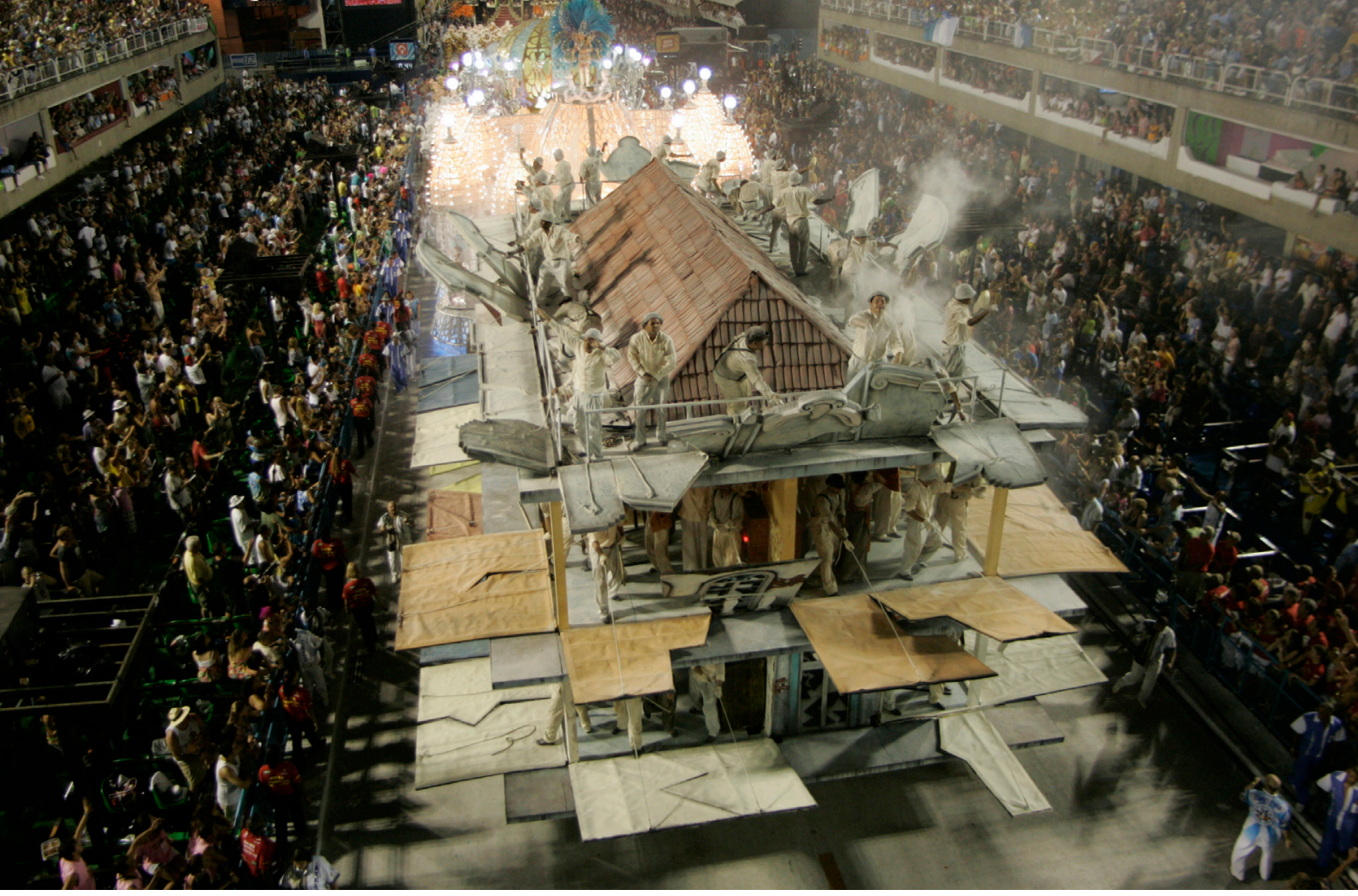

Figura 2: Alegoria da Vila Isabel em 2009 Foto: Henrique Matos (Centro de Memória da Liesa)

Tomamos emprestado o relato da experiência de Cavalcanti para analisar essa dimensão alegórica. A autora aponta para a articulação das alegorias com o processo social em torno do desfile e sugere que os carros alegóricos de certa forma traduzem e expressam a vida dos habitantes da cidade. Essa ideia de compartilhar o desfile das escolas de samba é que demanda uma linguagem popular por parte das alegorias. Podemos até dizer que ousadia e inovação estética com boa receptividade sinalizam público já maduro para essa nova fase estética - essa nova estética reflete a vida das pessoas. Do contrário, poderá estar instaurada uma problemática, uma negação das novas propostas.

Fragmentação - trata-se da decomposição dos elementos e unidades. Essas partes separadas se relacionam, mas conservam o caráter individual.

Os destaques e figuras centrais de carros alegóricos representam o mesmo tema que os demais elementos, mas conservam seu caráter individual. As pessoas que figuram como destaque das alegorias geralmente são figuras conhecidas da sociedade que, devido à indumentária, se separam visualmente do conjunto do carro que as transporta. Segundo Oliveira (2010) as fantasias de destaque 
Figura 3: Alegoria da Portela em 2008 Foto: Henrique Matos (Centro de Memória da Liesa)

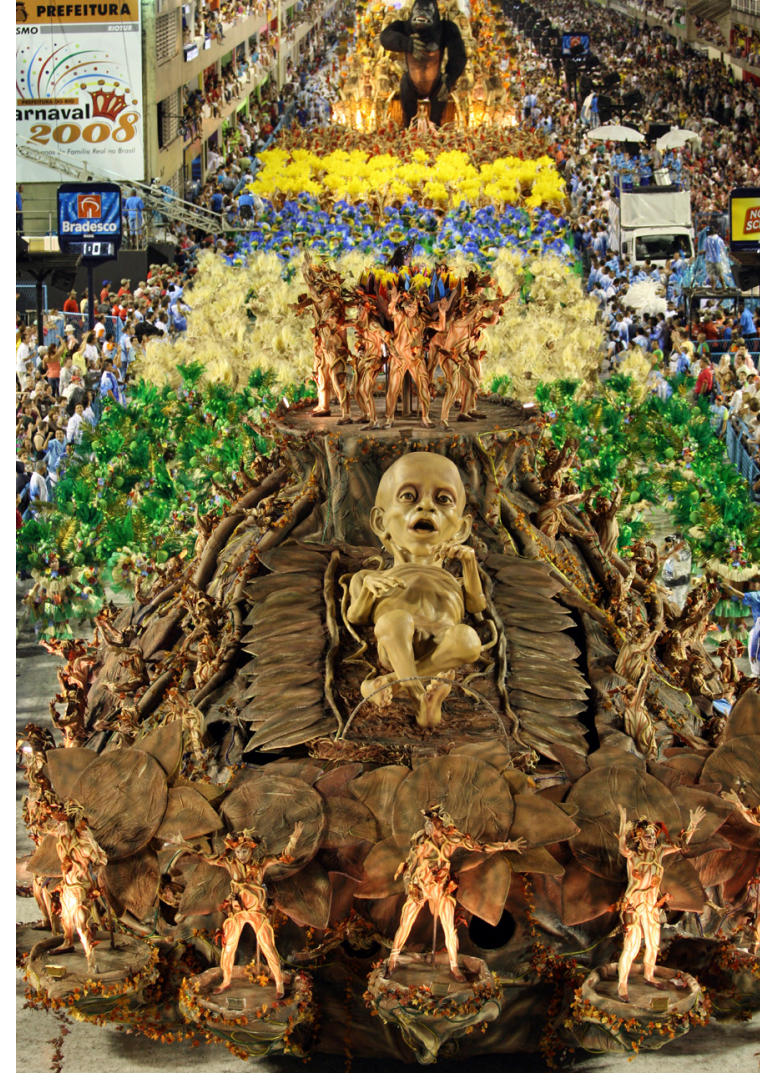

são aquelas fantasias únicas: extremamente rebordadas e elaboradas. Elas desfilam em cima das alegorias, ocupando locais "de destaque": central ou frontal. Algumas pessoas ainda subdividem as fantasias de destaque em "semidestaque", mas, para o entendimento em nosso trabalho, essas três categorias já são suficientes (p. 81).

Variação - oferece diversidade e sortimento. As mutações são controladas por um tema dominante.

Mais recentemente, o carnavalesco Paulo Barros tem efetivado e escancarado esse processo que não corresponde apenas às alegorias, mas às fantasias também. Em 2009, na Unidos de Vila Isabel, que tinha como tema "É minha Vila que anuncia: Theatro Muncipal - a centenária maravilha", o carnavalesco (em parceria com o carnavalesco Alex de Souza) projetou um carro alegórico (figuras 1 e 2) representando o processo de revitalização do Rio de Janeiro no governo de Pereira Passos: uma casa cujas paredes se abriam, para mostrar figurantes que representavam operários martelando, construindo, operando numa nova construção.

No ano anterior a Portela tinha como enredo "Reconstruindo a natureza, recriando a vida: o sonho vira realidade", do carnavalesco Cahê Rodrigues. Um 


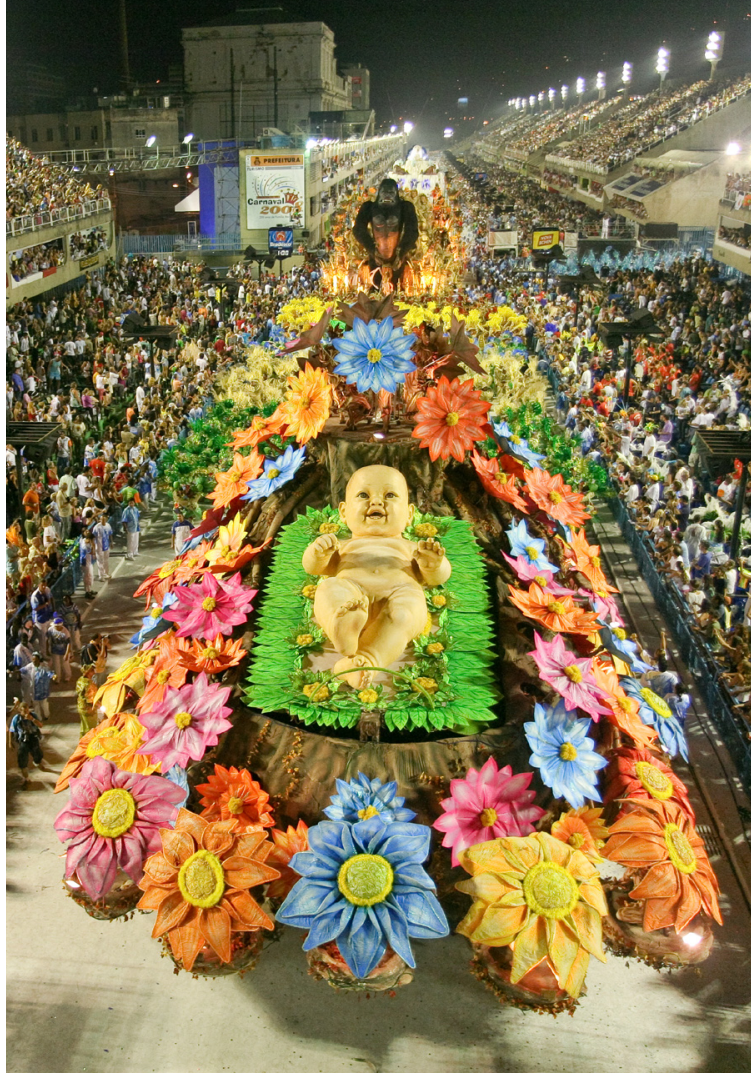

Figura 4: Alegoria da Portela em 2008 Foto: Henrique Matos (Centro de Memória da Liese)

dos carros (figuras 3 e 4) apresentava num primeiro momento um bebê desnutrido circundado por natureza inóspita, destruída. No segundo momento o mesmo carro se transformava num espetáculo de flores com um bebê saudável e sorridente. Era a representação da preservação da natureza.

Esse recurso de variação multiplica a apreciação alegórica e a torna mais complexa.

Colorismo - determina a intensificação do significado através das cores, com sua deliberada e embriagada utilização.

Na história da arte foram muitos os movimentos e escolas artísticas que souberam usar a carga cromática como expressão vigorosa de sentimentos. Os fauvistas bem o ilustram. Muito mais do que se valerem da cor para "representar"6 um objeto, usavam-na para intensificar a sentimentalidade comunicativa.

No desfile das escolas de samba essa função não é só percebida alegoricamente, mas também nas fantasias. É bonito ver uma escola completa na avenida apresentando nas roupas de suas alas dualidades, respostas, confrontos e contrastes de cores, formando um "rico tapete" pela unidade do conjunto.

Atividade - através da representação ou da sugestão, trata-se de postura enérgica, estimulante, de movimento. 


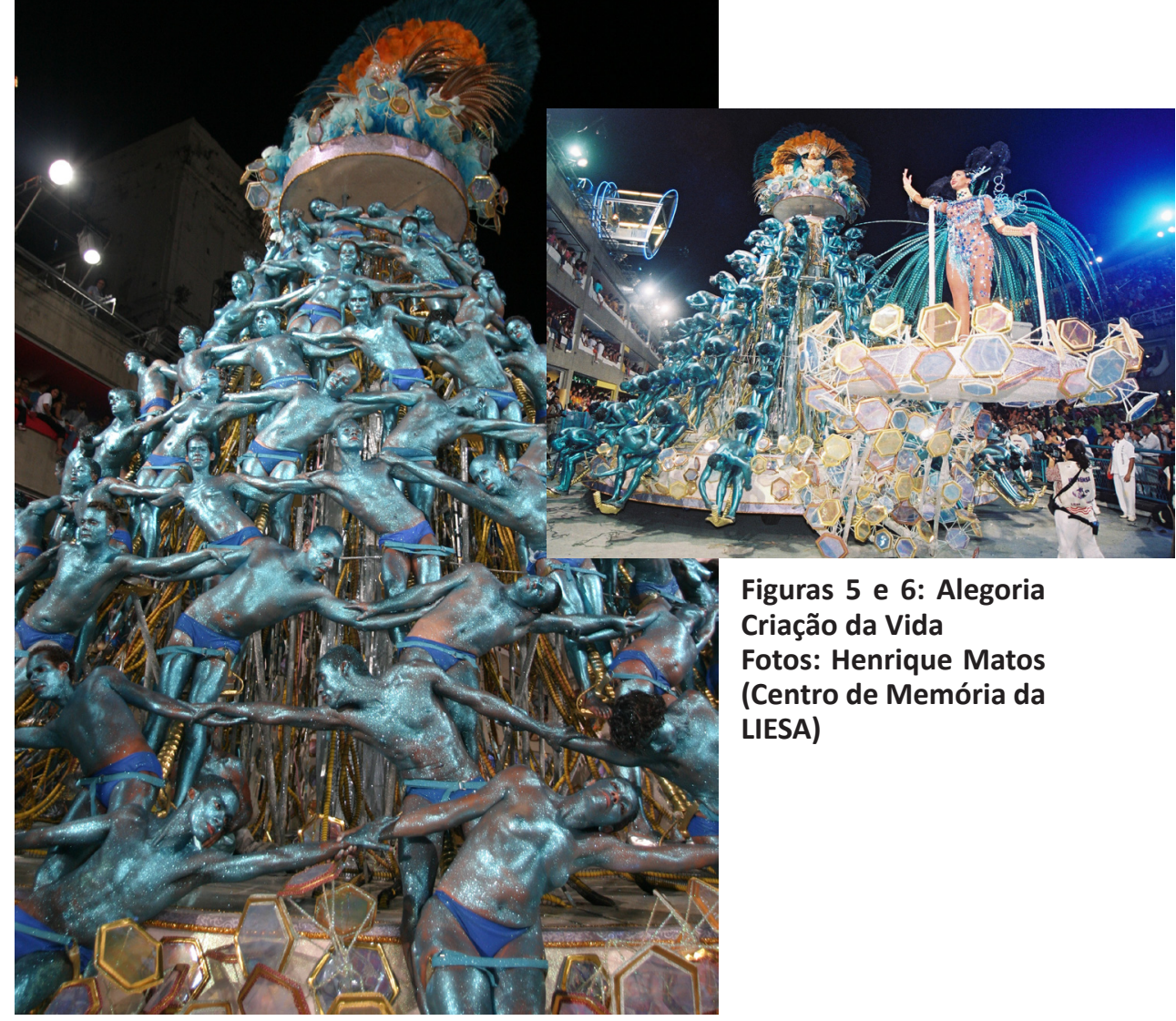

A ideia de colocar as pessoas nos carros, proporcionando performances; a questão tecnológica dos movimentos nos carros, tudo isso proporciona uma atividade efetiva nos corsos. Cavalcanti (2006) se refere a Joãozinho Trinta: "essa 'decoração' humana em seus carros, onde corpos humanos misturam-se com o carro pelo uso da cor e do movimento".

Inovador no carnaval contemporâneo, Paulo Barros vem-se valendo do recurso das "alegorias vivas", preenchidas por uma quantidade enorme de pessoas que fazem determinadas performances, como o famoso carro "Criação da Vida" (figuras 5 e 6), da Unidos da Tijuca, em 2004, que representava o código de DNA. Era uma pirâmide humana com 127 pessoas que, nuas da cintura para cima, pintadas de azul, coreografavam com sutileza e exaustão, abstraindo-se no carro dando uma ideia de moléculas, células, e de microelementos na enormidade do suporte. Era surpreendente como aquela quantidade de pessoas fazia um movimento não gratuito, narrando com propriedade a proposta do enredo. Paulo Barros consegue em seus carros, segundo Cassia Roberta Nogueira dos Santos (2009, p. 35 e 36), dar a "sensação de prolongamento, de continuidade. Carro e corpo se fundem num único signo". 


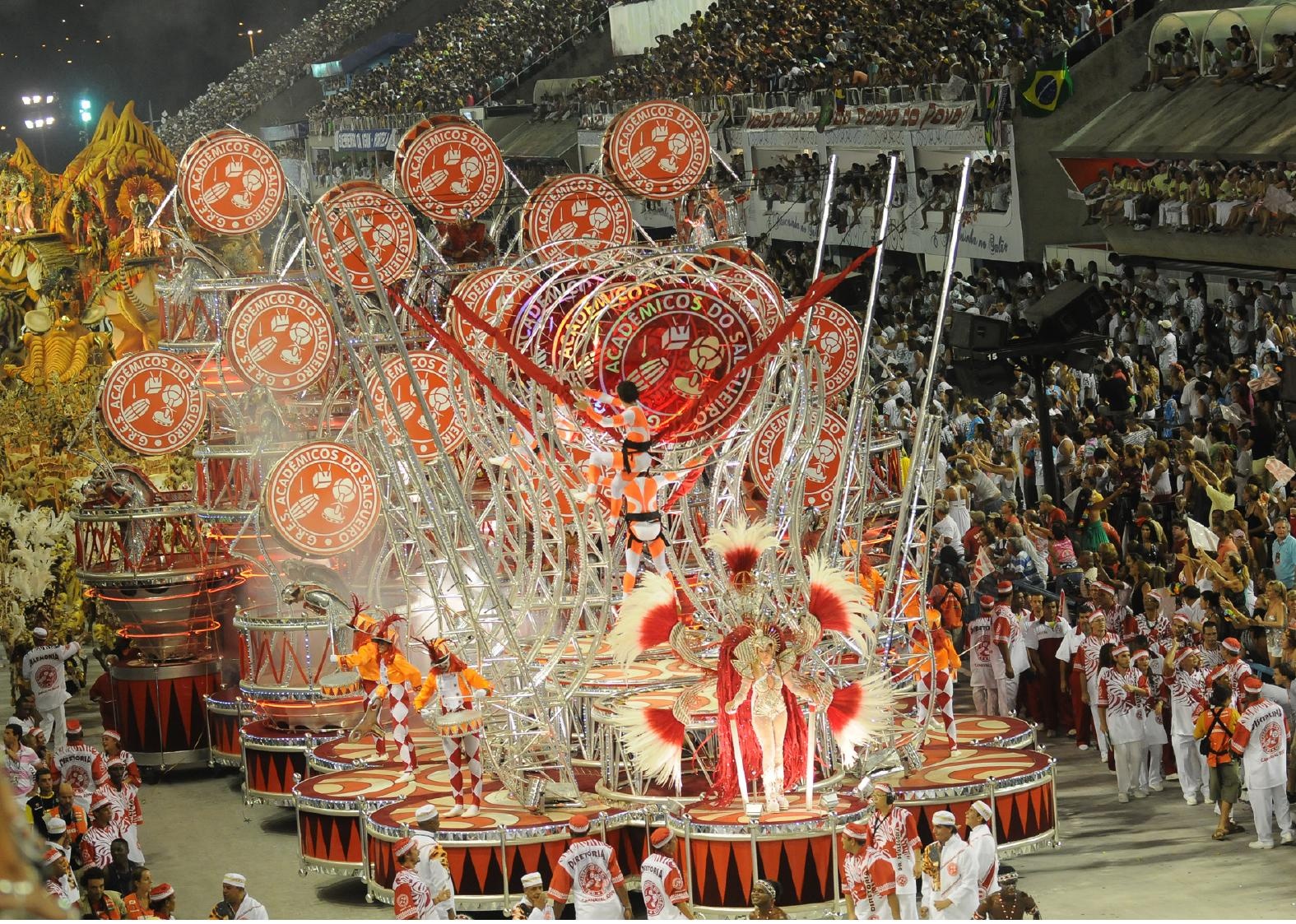

Figura 7: Alegoria do Salgueiro em 2009 Foto: Henrique Matos (Centro de Memória da Liesa)

Brilho - representa uma energia luminosa, que aparentemente lhe é própria. O objeto apresenta claridade superior à do resto do campo.

O brilho no desfile de escola de samba é, talvez, uma das técnicas mais recorrentes. Como o desfile é noturno, as luzes dos refletores ou recursos de iluminação que proporcionem boa visibilidade da escola nela se refletem, e ela "devolve" esse reflexo aos olhos do espectador através da utilização de cores que "reagem" à luz ou de elementos/materiais corriqueiros como acetatos, paetês, tons metalizados, pedrarias, entre outros. Praticamente todos os carros de escolas de samba têm recursos luminotécnicos (canhões de luz, neon, para citar os mais básicos), intensificando essa impressão de brilho. Em 2009, a Acadêmicos do Salgueiro apresentou o enredo "Tambor", do carnavalesco Renato Lage. A primeira alegoria da escola (Figura 7) apresentava cerca de 20 grandes tambores em movimento. Por baixo de alguns deles subiam luzes estroboscópicas que davam uma "impressão rítmica" convincente daquilo que a alegoria queria comunicar. Esse exemplo, considero uma excelente e certeira utilização da técnica brilho. 


\section{REFERÊNCIAS BIBLIOGRÁFICAS}

ARNHEIM, Rudolf. Arte e percepção visual: uma psicologia da visão criadora.Tradução de Ivonne Terezinha de Faria. São Paulo: Thomson Learning, 2006.

BARBOSA, Marília; SANTOS, Lígia. Paulo da Portela: Traço de união entre duas culturas. Rio de Janeiro: Funarte, 1980.

CARNEIRO, Edison. Prefácio. In EFEGÊ, Jota. Ameno Resedá, o rancho que foi escola. Rio de Janeiro: Ed. Letras e Artes, 1987.

CAVALCANTI, Maria Laura Viveiros de Castro. As alegorias no carnaval carioca: visualidade espetacular e narrativa ritual. Textos escolhidos de cultura e arte populares, Rio de Janeiro, v. 3, n. 1, p. 17-27, 2006.

. Carnaval carioca: dos bastidores ao desfile. Rio de Janeiro: Funarte/UFRJ, 1994.

COSTA, Haroldo. Salgueiro: Academia de Samba. Rio de Janeiro: Editora Record, 1984.

CUNHA, Milton. Rapsódia brasileira de Joãosinho Trinta: um grande leitor do Brasil! Tese (doutorado em ciência da literatura) - Universidade Federal do Rio de Janeiro. Rio de Janeiro, 2010.

DONDIS, Donis A. Sintaxe da Linguagem Visual. Tradução Jefferson Luiz Camargo. 2. ed. São Paulo: Martins Fontes, 1997.

FERREIRA, Felipe. O livro de ouro do carnaval brasileiro. Rio de Janeiro: Ediouro, 2004.

MOURA, Roberto. Tia Ciata e a pequena África do Rio de Janeiro. Rio de Janeiro: Funarte, 1893.

OLIVEIRA, Madson Luis Gomes de. Imaginários da criação: o tempo e o espaço dos souvenirs carnavalescos. Tese (doutorado em design) - Universidade Federal do Rio de Janeiro. Rio de Janeiro, 2010.

SANTOS, Cássia Roberta Nogueira dos. Alegoria Viva. Corpo como produtor de signo. Monografia (licenciatura em dança) - Faculdade Angel Vianna. Rio de Janeiro, 2009.

SANTOS, Nilton Silva dos. Estilo autoral e individualidade artística: os carnavalescos do carnaval carioca. In: CAVALCANTI, Maria Laura; GONÇALVES, Renata (Orgs.). Carnaval em múltiplos planos. Rio de Janeiro: Aeroplano, 2009.

. "Carnaval é isso aí. A gente faz para ser destruído!": Carnavalesco, individualidade e mediação cultural. Tese (doutorado em ciências humanas) - Universidade Federal do Rio de Janeiro. Rio de Janeiro, 2006.

\section{NOTAS}

$1 \mathrm{E}$, diga-se de passagem, que o julgamento do desfile é a culminância de um longo processo de concepção e confecção de um projeto que parte geralmente do carnavalesco e sua proposta de enredo.

2 Sobre a questão do julgamento das escolas de samba, ver Cavalcanti, 1994. 
3 Penso que a monumentalidade é o recurso óbvio para a construção de um espetáculo carnavalesco, por motivos já apresentados e que ainda serão retomados. À medida que os desfiles de escolas de samba foram crescendo social e visualmente essa verticalização e grande volumetria alegórica foi demandando espaço cênico maior (em grande parte das cidades em que existe carnaval esse espaço já está estabelecido com considerável tamanho), e assim todas as escolas tendem a projetar espetáculo compatível com esse ambiente.

4 Dondis não identifica a simetria, como técnica ornamental. No caso específico do desfile de escolas de samba, porém, creio ser um recurso visual preciso devido a essa necessidade que identificamos na linguagem feita "para a avenida".

5 Segundo o regulamento da Liesa, cada jurado concede uma nota de 8 a 10, podendo ser fracionada em décimos. Há subentendida a possibilidade de uma escola perder pontos durante o desfile, ou seja, ela começa com 10 pontos, e à medida que o jurado identifica falhas em seu quesito ele tira ponto. $O$ regulamento exige que o jurado justifique a nota abaixo de 10, o que faz com que uma escola que tire $10 \mathrm{em}$ geral não receba comentário algum, exceto um "parabéns" ou "excelente". Isso, entretanto, não significa que a justificativa só apresente aspectos negativos. É possível conhecer a percepção do jurado a respeito de pontos positivos e negativos da escola, ambos apresentados na planilha de julgamento.

6 Ver, sobre "anatomia da mensagem visual", Dondis, 1997, p.85.

Pedro Ubirajara Rosa é graduando de licenciatura plena em artes visuais pela Universidade de Caxias do Sul. Atualmente é bolsista voluntário da Universidade de Caxias do Sul na área da antropologia.

Recebido em: 27/05/2012

Aceito em: 04/07/2012 
